\title{
Episodic ataxia in CASPR2 autoimmunity
}

A. Sebastian López Chiriboga, MD, and Sean Pittock, MD

Neurol Neuroimmunol Neuroinflamm 2019;6:e536. doi:10.1212/NXI.0000000000000536

A 64-year-old man developed cognitive dysfunction and generalized seizures, followed by episodes of transient speech and gait disturbances lasting several minutes, occurring multiple times per day; the events were not associated with any triggers. Neurologic examination during one of his episodic symptoms (video 1) showed transient ataxic dysarthria. Testing for neural autoantibodies revealed evidence of voltage-gated potassium channel complex antibodies by radioimmunoprecipitation assay; CASPR2-IgG was positive in serum and CSF by cell-based assay. Brain MRI was normal; CSF analysis showed an elevated protein level at $101 \mathrm{mg} / \mathrm{dL}$, but it was otherwise normal. Oncologic evaluation was negative. The cognitive symptoms improved; seizures and episodic ataxia resolved after 12 weeks of treatment with IV methylprednisolone. Episodic ataxia is a manifestation of CASPR2 autoimmunity; ${ }^{1}$ patients can have normal MRI, and immunotherapy is beneficial.

\section{Author contributions}

A.S. Lopez-Chiriboga and S. Pittock contributed to the conception and design of the study; collection, analysis, and interpretation of the data; drafting and critical revision of the manuscript; and generation/collection of the figures. Both authors gave final approval of the manuscript.

\section{Study funding}

No targeted funding reported.

\section{Disclosure}

A.S. Lopez-Chiriboga reports no disclosures. S. Pittock has a patent pending for GFAP, Septin5 and MAP1B autoantibodies as biomarkers of neurological autoimmumity; received research support from Grifols, MedImmune, Alexion, AEA, and NIH; had compensation for consulting activities paid to Mayo Clinic from Alexion and MedImmune; and has a financial interest with Mayo Clinic in patents that relate to functional AQP4/NMO-IgG assays and NMO-IgG as a cancer marker. Full disclosure form information provided by the authors is available with the full text of this article at Neurology.org/NN.

\section{Publication history}

Received by Neurology: Neuroimmunology \& Neuroinflammation September 27, 2018. Accepted in final form November 8, 2018.

\section{Reference}

1. Joubert B, Gobert F, Thomas L, et al. Autoimmune episodic ataxia in patients with anti-CASPR2 antibody-associated encephalitis. Neurol Neuroimmunol Neuroinflamm 2017;4:e371. doi: 10.1212/NXI.0000000000000371.
Correspondence

Dr. López

lopez.alfonso@mayo.edu

MORE ONLINE

○ Video

From the Department of Neurology (A.S.L.C.) and Laboratory Medicine and Pathology (S.P.), Mayo Clinic, Rochester, MN.

Funding information and disclosures are provided at the end of the article. Full disclosure form information provided by the authors is available with the full text of this article at Neurology.org/NN.

The Article Processing Charge was funded by the authors.

This is an open access article distributed under the terms of the Creative Commons Attribution-NonCommercial-NoDerivatives License 4.0 (CC BY-NC-ND), which permits downloading and sharing the work provided it is properly cited. The work cannot be changed in any way or used commercially without permission from the journal. 


\title{
Neurology \\ Neuroimmunology \& Neuroinflammation
}

\author{
Episodic ataxia in CASPR2 autoimmunity \\ A. Sebastian López Chiriboga and Sean Pittock \\ Neurol Neuroimmunol Neuroinflamm 2019;6; \\ DOI 10.1212/NXI.0000000000000536
}

This information is current as of December 24, 2018

\section{Updated Information \& Services}

References

Subspecialty Collections

Permissions \& Licensing

Reprints including high resolution figures, can be found at:

http://nn.neurology.org/content/6/2/e536.full.html

This article cites 1 articles, 1 of which you can access for free at: http://nn.neurology.org/content/6/2/e536.full.html\#\#ref-list-1

This article, along with others on similar topics, appears in the following collection(s):

All Clinical Neurology

http://nn.neurology.org//cgi/collection/all_clinical_neurology

Clinical neurology examination

http://nn.neurology.org//cgi/collection/clinical_neurology_examination

Gait disorders/ataxia

http://nn.neurology.org//cgi/collection/gait_disorders_ataxia

Information about reproducing this article in parts (figures,tables) or in its entirety can be found online at:

http://nn.neurology.org/misc/about.xhtml\#permissions

Information about ordering reprints can be found online: http://nn.neurology.org/misc/addir.xhtml\#reprintsus

Neurol Neuroimmunol Neuroinflamm is an official journal of the American Academy of Neurology.

Published since April 2014, it is an open-access, online-only, continuous publication journal. Copyright

Copyright (C) 2018 The Author(s). Published by Wolters Kluwer Health, Inc. on behalf of the American

Academy of Neurology.. All rights reserved. Online ISSN: 2332-7812.

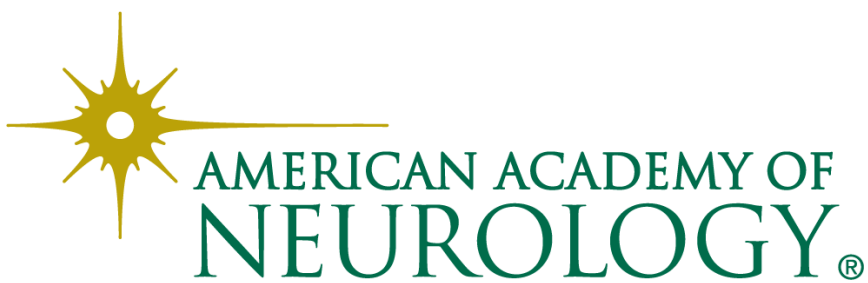

